\title{
Analysis of Social, Psychological and Other Factors on College Dropout Rates among African American Students
}

\author{
Salam Khan \\ Department of Physics, Chemistry and Mathematics, Alabama A\&M University, Normal, AL, USA \\ Email: salam.khan@aamu.edu
}

How to cite this paper: Khan, S. (2017). Analysis of Social, Psychological and Other Factors on College Dropout Rates among African American Students. Advances in Applied Sociology, 7, 319-326. https://doi.org/10.4236/aasoci.2017.78020

Received: July 17, 2017

Accepted: August 14, 2017

Published: August 17, 2017

Copyright $\odot 2017$ by author and Scientific Research Publishing Inc. This work is licensed under the Creative Commons Attribution International License (CC BY 4.0).

http://creativecommons.org/licenses/by/4.0/

(c) (i) Open Access

\begin{abstract}
This study explored the African American college students' retention behavior and identifies the effect of different social, psychological and other factors. Randomly selected students from predominant African American university completed the perceived stress scale, self-motivation scale, parental involvement, childhood economic situation, mentorship and drug and alcohol use questionnaire. Non-parametric analyses suggested that higher stress level, childhood poverty, lack of parental involvement or support, without a mentor support and lack of self-motivation increase the likelihood of dropping out from college. This study's findings have important implications for college retention among African American students.
\end{abstract}

\section{Keywords}

Dropout Rate, Retention, Psychological Factors, Social Factors, African American Students

\section{Introduction}

Among African American students high levels of stress are already a main characteristic of most college students today. Most of them have part time jobs and the need to support themselves, as well as children, and any other family responsibilities, students can be pushed to their breaking point. Homework, and study time can often be left to the wayside in favor of working and, or childcare. Yet, and still, even students who do not need to provide for themselves, or who do not have children still often fail, or barely pass courses.

Many African American individuals are motivated and qualified to attend college but face significant challenges to achieving this goal. This is particularly 
noteworthy for Black men in higher education. According to Kim \& Hargrove (2013): "Despite holding high aspirations to attend college, Black men comprised less than $6 \%$ of the entire U.S. undergraduate population in 2010 (U.S. Department of Education, National Center for Education Statistics, 2012b). According to Toldson (2012), although college enrollment rates for Black men are proportional to Black male representation in the adult U.S. population, college attainment rates fall far short of these numbers....Additional evidence shows that almost $70 \%$ of Black men do not complete a college degree within six years, compared with 57\% of the overall undergraduate student population (Harper, 2006)". Family support is often crucial to a student's pursuit of higher education. According to Strayhorn (2010), "one way in which families play a role in the academic success of students is through parental involvement". A parent attending school meetings and thus being involved with the school process was found to be associated with high achievement in math among Black students (Strayhorn, 2010). Such parents were more likely to be knowledgeable about resources available at the school, the progress of their children, and problems they needed to address. Parents' high expectations for their children created a system for lasting perceptions and values, which often contributed to success in school (Strayhorn, 2010). Parental involvement has been noted in many research studies as a key component of successful students. According to Foster \& Tillman (2009), consensus exists that there is a direct link between parental involvement and the success of students among researchers, district and school personnel, and state and federal policymakers. Morales (2010) found that active parental involvement has a positive effect on the academic achievement of African American students. Parental involvement is important for all students; however, it is especially important in the urban schools that Black students attend (Foster \& Tillman, 2009). A study by Williams \& Bryan (2013) explored factors contributing to resiliency in Black youth, and found that realistic expectations concerning academic performance served as a source of motivation. But Many African American students are first generation college students. They do not receive proper guidance and mentoring from their family as first generation college students. Many of them fail college or drop out of the college due to lack of motivation to continue the study.

According to the research on resiliency, many Black youth have attributed their success in high school to having mentorship from an adult (Williams \& Bryan, 2013). When the student completes high school, however, this need for mentorship does not end. Despite the increase in the number of Black students in higher education, once there, they often experience a struggle to fit in and do well. In order to assist with this difficult situation, mentorship programs have been established in high schools and colleges to connect Black students with individuals who have succeeded in higher education and can relate to the students' experiences. Research has shown that having a mentor in high school may help encourage adolescents to see education as an opportunity for personal advancement (Hurd, Sanchez, Zimmerman, \& Caldwell, 2012), as mentors provide ex- 
amples of linking education to: (a) their present success, (b) stronger beliefs in the importance of school for future success, and (c) indirectly to enhanced views of the importance of school for adolescents (Hurd et al., 2012).

An understanding of the psychological factors in addition to other factors that place university students at greater risk for substance usage and abuse is critical for the development of effective intervention and preventative measures. Substance abuse among university students within the United States has been a major public health problem (Dhanookdhary \& colleagues, 2010; Ham \& Hope, 2003) and has been linked to the adverse consequences of suicide, negative educational outcomes, criminal behaviors, psychological difficulties, and severe drug abuse (Windle, 2003). Compared to the general population, university students are at greater risk due to their particular surroundings. The U.S. Department of Health and Human Services (1997), stated that, 18-24 year olds (the typical age range for university students) have the highest usage rate compared to other age groups. There are a multitude of reasons why university students use drug and alcohol. These include peer pressure, conformity, and managing stress (O'Hare \& Sherrer, 2000). Deas \& Thomas (2002) also stated that stressful and/or traumatic events also suggest an increased risk for developing drug or alcohol usage. Such findings were made evident by Kilpatrick et al. (2000) whose research found that adolescents who witnessed and experienced stressful, violent, or traumatic situations were more inclined to experiment with various substances such as alcohol and other drugs.

Deas \& Thomas (2002) define psychological factors as "patterns of thought and behavior that exist along a continuum in the general population-including for example, personality traits, self-esteem, and coping skills". Psychological factors are generally related to behaviors and thought patterns that may influence any particular action such as drop out of college. Studies have shown that psychological factors have been related to increase risk involving personality patterns of high novelty seeking, low harm avoidance, and high reward dependence.

\section{Objectives}

This study evaluated and understood African American undergraduate students about their dropping out reasons. The rationale for studying this population is based on the fact that there is high dropout rate among African American undergraduate students. This may ultimately lead them to vicious poverty cycles. Thus with structured intervention and prevention programs may be implemented in universities within the United States. This study explored the college students' drop out behavior and identifies the effect of different social and psychological factors.

\section{Methodology}

The participants of this study included 200 individuals who are undergraduate 
students at Alabama A\&M University (AAMU), a Historically Black College and University (HBCU) in Normal, Alabama.

The following variables are being used in this study: stress level, self-motivation level, parental involvement, childhood economic situation, mentorship and drug and alcohol use. The following appendices will address these variables.

1) Demographics Form-Participants required to provide information about their age, gender, ethnicity, residence, family income and parents' education, parental involvement/support of their education, mentor support on the questionnaire but not their names.

2) The Youth Survey Questionnaire. Developed by the World Health Organization to collect information on the use of alcohol. Atowi et al. (2011) and Peltzer, Malaka, \& Phaswana (2002) have both reported using the Model Core Questionnaire to obtain information with respect to alcohol, tobacco and marijuana. The participants was asked, (ii) what they have used over the past 30 days, (iii) average amount consumed per episode (iv) maximum number of drinks consumed in a two-hour period.

3) The Perceived Stress Scale (PSS) (Cohen, Kamarck, \& Mermelstein, 1983) is a 10-point scale based upon the participants' feelings and thoughts over the previous month. The scale is responded on a 4-point Likert Scale (Never to very often).

4) The Perceived self-motivation is a 10-point scale based upon the participants' feelings (None to very high).

5) Childhood economic situation is responded on a 4-point scale (Very poor to very affluent).

6) Parental involvement/support toward education is responded on a 4-point scale (No parental support to high parental support).

7) Self-motivation is responded on a 4-point scale (No self-motivation to high self-motivation).

8) Mentor support is responded on a 4-point scale (No mentor support to high mentor support).

9) Dropout represented by a dichotomous variable 0 and 1.0 represent did not drop-out and 1 represent drop-out.

Participants asked to complete the demographics form. Participants also completed the Youth Survey Questionnaire to assess the use of alcohol. The PSS was being served as an additional scale to measure stress among students.

Once the study has been completed and turned into the proctor, each participant was thanked for willingly participating in the study. Each participant was then being debriefed in regards to the purpose and objectives of the study.

The SPSS (Statistical Package for Social Sciences) or SAS (Statistical Analysis System) was being used to obtain descriptive and non-parametric inferential analysis of the data. Spearman rank correlations were used to determine the strength of the association between the variables. The initial hypothesis was that there is no association between alcohol usage and psychological factors. 


\section{Data Analysis}

We analyzed the data to find the association between the drop outs and stress levels by using Spearman rank correlation. From Table 1 we can see that they have significant positive correlation among them and the Spearman rank correlation is 0.253007 . That is higher stress level is associated with drop outs.

We analyzed the data to find the association between the drop outs and childhood economic situation by using Spearman rank correlation. From Table 2 we can see that they have significant negative correlation among them and the Spearman rank correlation is -0.41505 . That is childhood poverty is associated with drop outs.

We analyzed the data to find the association between the drop outs and parental involvement or support by using Spearman rank correlation. From Table 3 we can see that they have significant negative correlation among them and the Spearman rank correlation is -0.38506 . That is low parental support or involvement is associated with drop outs.

We analyzed the data to find the association between the drop outs and selfmotivation by using Spearman rank correlation. From Table 4 we can see that they have negative correlation among them and the Spearman rank correlation is -0.363997 . That is low self-motivation is associated with drop outs.

We analyzed the data to find the association between the drop outs and mentor support by using Spearman rank correlation. From Table 5 we can see that they have negative correlation among them and the Spearman rank correlation

Table 1. Spearman rank correlation between drop out and stress level among African American students.

\begin{tabular}{ccc}
\hline Variable & Drop out & Stress \\
\hline Drop out & 1.0 & 0.253007 \\
Stress & 0.253007 & 1.0 \\
\hline
\end{tabular}

Correlations are significant at $p<0.05$.

Table 2. Spearman rank correlation between drop out and childhood economic situation among African American students.

\begin{tabular}{ccc}
\hline Variable & Drop out & Childhood economic situation \\
\hline Drop out & 1.0 & -0.41505 \\
Childhood economic situation & -0.41505 & 1.0 \\
\hline
\end{tabular}

Correlations are significant at $p<0.05$.

Table 3. Spearman rank correlation between drop out and parental involvement or support among African American students.

\begin{tabular}{ccc}
\hline Variable & Drop out & Parental support \\
\hline Drop out & 1.0 & -0.38506 \\
Parental support & -0.38506 & 1.0 \\
\hline
\end{tabular}

Correlations are significant at $p<0.05$. 
Table 4. Spearman rank correlation between drop outs and self-motivation among African American students.

\begin{tabular}{ccc}
\hline Variable & Drop out & Self-Motivation \\
\hline Drop out & 1.0 & -0.363997 \\
Self-Motivation & -0.363997 & 1.0 \\
\hline
\end{tabular}

Correlations are significant at $p<0.05$.

Table 5. Spearman rank correlation between drop outs and mentor support among African American students.

\begin{tabular}{rcc}
\hline Variable & Drop out & Mentor support \\
\hline Drop out & 1.0 & -0.563995 \\
Mentor support & -0.563995 & 1.0 \\
\hline
\end{tabular}

Correlations are significant at $p<0.05$.

is -0.563995 . That is low or no mentor support is associated with drop outs.

We also analyzed the data to find the association between the drop outs and drug and alcohol use. By using Spearman rank correlation we found no significant association among drug alcohol use with drop outs.

\section{Discussion and Conclusion}

In this study we explored how different social and psychological factors affect the African American undergraduate college students' drop out behavior. Here we considered social and psychological factors: stress, self-motivation, parental involvement/support, childhood economic situation, mentor support and drug and alcohol use. There are about 200 respondents from Alabama A\&M University. Respondent's average age is 22 years and respondent's age lies between 18 to 30 years.

We analyzed the data to find the association between the drop out behavior and stress level, self-motivation level, parental involvement/support, childhood economic situation, mentor support and drug and alcohol use.

The associations between the drop outs and stress levels have significant positive correlation among them and the Spearman rank correlation is 0.253007 . That is higher stress level is associated with drop outs for the African American students. As most of them work in high levels of stress drop-out rate can be reduced by reducing their financial stress with scholarships and other funding opportunities.

The associations between the drop outs and childhood economic situation have significant negative correlation among them and the Spearman rank correlation is -0.41505 . That is childhood poverty is highly associated with drop outs. Because of the childhood poverty many of them did not get a chance of better education. That is why many of them are unprepared or underprepared for the college and after entering college get overwhelmed with the college study and many of them drop-out because of this situation. Disadvantageous students need 
support for better education from very early age and that kind of support system will decrease drop-outs among African American students.

The associations between the drop outs and parental involvement or support have significant negative correlation among them and the Spearman rank correlation is -0.38506 . That is low parental support or involvement is highly associated with drop outs. Many of them are growing up with single parent or no parent. Most of them are first generation college students. Parental support will decrease the decrease drop-outs among African American students.

The associations between the drop outs and self-motivation have negative correlation among them and the Spearman rank correlation is -0.363997 . That is low self-motivation is highly associated with drop outs. African American students need to attend some program to increase their self-motivation to decrease drop-outs.

The associations between the drop outs and mentor support have negative correlation among them and the Spearman rank correlation is -0.563995 . That is low or no mentor support is highly associated with drop outs. From this study we see that lack of mentor support is highly associated with drop outs and it is one of the major factors of drop-outs. As many of them are growing up with single parent or no parent and most of them are first generation college students. They need constant guidance to succeed in life.

The association between the drop outs and drug and alcohol use is statistically insignificant.

Although the sample size was small and therefore cannot be generalized to the population as a whole, much useful information can be extracted from this study.

One final conclusion was these students' belief that college was a given, they could not imagine anything else after high school. This expectation was not only one they had for themselves but was reinforced by families, schools and peers, and key to their feeling confident enough to pursue their journey even when presented with challenges.

The above analyses suggested that higher stress level, childhood poverty, lack of parental involvement or support, without mentor support and lack of self-motivation increase the likelihood of dropping out from college.

\section{References}

Atowi, L., Mungla, P. A., Ndunga'u, M. N., Kinoti, K. C., \& Ogot, E. M. (2011). Prevalence of Substance Use among College Students in Eldoret, Western Kenya. BMC Psychiatry, 11, 34. https://doi.org/10.1186/1471-244X-11-34

Cohen, S., Kamarck, T., \& Mermelstein, R. (1983). A Global Measure of Perceived Stress. Journal of Health and Social Behaviours, 24, 385-396. https://doi.org/10.2307/2136404

Deas, D., \& Thomas, S. (2002). Comorbid Psychiatric Factors Contributing to Adolescent Alcohol and Other Drug Use. Bethesda, MA: National Institute on Alcohol Abuse and Alcoholism.

Dhanookdhary, A. M. R., Gomez, K., Lall, A., Murray, D., Prabhu, D., Ragoonath, A., 
Singh, N., Tewari, S., \& Youssef, F. F. (2010). Substance Use among University Students at the St Augustine Campus of the University of the West Indies. West Indian Medical Journal, 59, 641-649.

Foster, L., \& Tillman, L. C. (2009). African American Perspectives on Leadership in Schools: Building a Culture of Empowerment. Lanham, MA: Rowman \& Littlefield Education.

Ham, L. S., \& Hope, D. A. (2003). College Students and Problematic Drinking: A Review of the Literature. Clinical Psychology Review, 23, 719-759.

https://doi.org/10.1016/S0272-7358(03)00071-0

Harper, S. R. (2006). Peer Support for African American Male College Achievement beyond Internalizing Racism and the Burden of “Acting White." The Journal of Men's Studies, 14, 337-358. https://doi.org/10.3149/jms.1403.337

Hurd, N. M., Sanchez, B., Zimmerman, M. A., \& Caldwell, C. H. (2012). Natural Mentors, Racial Identity, and Educational Attainment among African American Adolescents: Exploring Pathways to Success. Child Development, 83, 1196-1212. https://doi.org/10.1111/j.1467-8624.2012.01769.x

Kilpatrick, D. G., Acierno, R., Saunders, B., Resnick, H. S., Best, C. L., \& Schnurr, P. P. (2000). Risk Factors for Adolescent Substance Abuse and Dependence: Data from a National Sample. Journal of Consulting and Clinical Psychology, 68, 19-30. https://doi.org/10.1037/0022-006X.68.1.19

Kim, K., \& Hargrove, D. T. (2013). Deficient or Resilient: A Critical Review of Black Male Academic Success and Persistence in Higher Education. The Journal of Negro Education, 82, 300-311. https://doi.org/10.7709/jnegroeducation.82.3.0300

Morales, E. E. (2010). Linking Strengths: Identifying and Exploring Protective Factor Clusters in Academically Resilient Low-Socioeconomic Urban Students of Color. Roeper Review, 32, 164-175. https://doi.org/10.1080/02783193.2010.485302

O'Hare, T., \& Sherrer, M. V. (2000). Co-Occurring Stress and Substance Abuse in College First Offenders. Journal of Human Behavior in the Social Environment, 3, 29-44. https://doi.org/10.1300/J137v03n01_02

Peltzer, K., Malaka, D. W., \& Phaswana, N. (2002). Sociodemographic Factors, Religiosity, Academic Performance, and Substance Use among First-Year University Students in South Africa. Psychological Reports, 91, 105-113.

https://doi.org/10.2466/pr0.2002.91.1.105

Strayhorn, T. L. (2010). The Role of Schools, Families, and Psychological Variables on Math Achievement of Black High School Students. The High School Journal, 93, $177-$ 194. https://doi.org/10.1353/hsj.2010.0003

Toldson, I. A. (2012). When Standardized Tests Miss the Mark. The Journal of Negro Education, 81, 181-185. https://doi.org/10.7709/jnegroeducation.81.3.0181

U.S. Department of Education, National Center for Education Statistics (2012b). The Condition of Education 2012 (NCES 2012-045). Washington DC: U.S. Department of Education, National Center for Education Statistics.

U.S. Department of Health and Human Services (1997). Ninth Special Report to the U.S. Congress on Alcohol and Health. Washington DC: U.S. Government Printing Office.

Williams, J. M., \& Bryan, J. (2013). Overcoming Adversity: High-Achieving African American Youth's Perspectives on Educational Resilience. Journal of Counseling and Development, 91, 291-300. https://doi.org/10.1002/j.1556-6676.2013.00097.x

Windle, M. (2003). Alcohol Use among Adolescents and Young Adults. Alcohol Research and Health, 27, 79-85. 
Submit or recommend next manuscript to SCIRP and we will provide best service for you:

Accepting pre-submission inquiries through Email, Facebook, LinkedIn, Twitter, etc. A wide selection of journals (inclusive of 9 subjects, more than 200 journals)

Providing 24-hour high-quality service

User-friendly online submission system

Fair and swift peer-review system

Efficient typesetting and proofreading procedure

Display of the result of downloads and visits, as well as the number of cited articles Maximum dissemination of your research work

Submit your manuscript at: http://papersubmission.scirp.org/

Or contact aasoci@scirp.org 